\title{
IMPEDIMENTS TO EFFICIENT FERTILIZER APPLICATION AMONG SMALL HOLDER FARMERS ON MARGINAL SOILS OF ABA AGRICULTURAL ZONE, NIGERIA: IMPLICATION FOR EXTENSION
}

\author{
*NWAOGWUGWU, O.N. AND **ULEBOR, J.U \\ *Department of Agricultural Economics \& Extension, University of Port Harcourt \\ **Department of Agricultural Education, College of education, Agbor, Nigeria \\ Corresponding author's E-mail obiawhite@ya
}

\begin{abstract}
The study investigated the impediments to efficient fertilizer application amongst small holder farmers on marginal soils of Aba Agricultural zone, Abia State. Five blocks were randomly selected out of thirteen existing blocks. Fifty respondents were randomly sampled from each block for data collection using structured questionnaire. Analysis of data was carried out using descriptive statistical tools. The results showed that farmers apply fertilizers at the appropriate time (mean $=4.34)$, farmers do not apply appropriate rate of fertilizers to attract a yield response (mean $=2.83$ ), farmers do not adopt proper application methods (mean $=3.20)$. It was therefore recommended that extension services should be intensified in the rural communities through establishment of demonstration plots, regular agricultural extension agents' visits, workshops and training for small-holder farmers on efficient fertilizer use.
\end{abstract}

Keywords: Impediments, Fertilizer application, Marginal Soils.

\section{INTRODUCTION}

The rainforest zone of Nigeria stretches from the mangrove swamps of the deltas to the upland plains, running West-eastwards through Ibadan, Benin, across the Niger to the Oban hills in Cross River State. Embedded in this zone is Aba agricultural zone in Abia State, Nigeria. The soil-types of this zone are inherently low in major soil nutrients and trace elements to support arable crop production (Iwuafor and Kuma, 1995). This deficiency is widespread and worsened by bush burning and crop residue removal, continuous leaching of soil mineral elements, erosion of soil particles and attendant degradation of arable lands. Consequently most of these soil-types are physically fragile and chemically suffer from ionic imbalance, acidity, especially those with low buffering capacity. These characteristics are associated with marginal soils.

Over the years, small-holder arable farmers have grappled with the above adverse soil condition using the traditional land rotation, shifting cultivation characterized by bush fallow and slash and burn. This system operates effectively under subsistence farming and where there is sufficient arable land to allow a long fallow period for natural soil fertility replenishment for crop growth and yield in a cropping cycle. In recent times, there is increasing land pressure as a result of rapid population growth. Urban encroachment and other non-agricultural land uses. However, to overcome these challenges and maintain a sustained food production for the teeming population, farmers have been encouraged to seek refuge in the use of chemical fertilizers. This is because considerable evidence suggests that stable and high crop yield can be realized through great and more efficient fertilizer use (FAO, 1960; Ofori, 1973; Kang et.al, 1977). McGraw Hill Encyclopedia of Food, Agriculture and Nutrition (1977) saw Fertilizer as by-products from chemical manufacturing Operations or natural materials added to the soil to supply elements essential for plant nutrition. A fertilizer mixture used widely in many soils contain major elements as Nitrogen $(\mathrm{N})$, Phosphorus (P) and Potassium (K), although secondary elements such as Sulphur (S), 
Magnesium ( $\mathrm{Mg}$ ) and trace elements such as Iron (Fe), Manganese (Mn), Boron (B), Copper $(\mathrm{Cu})$, Zinc ( $\mathrm{Zn})$ and Molybdenum (Mo) are essential for some crops in certain environments (fertilizer use Committee (FUC) 1980; FAO, 1960). Chemical fertilizers are generally classified on the basis of the main plant nutrients - Nitrogen, Phosphorus and Potassium as Nitrogenous, Phosphatic and Potassic fertilizers while that having more than one nutrient is termed mixed or compound fertilizer.

The need for efficient fertilizer application cannot be over-emphasized. This becomes critical especially in developing nations such as Nigeria faced with the challenge of food insecurity. Many rural farmers in Aba agricultural zone over the years, procure and apply fertilizers with approximately the correct ratio of nutrient elements, but fail to secure the corresponding yield increase. This incident has been recurrent and sometimes leading to general crop failure for various food crops in the zone. Sometimes fertilization is done without considering the type, level and performance of the fertilizer in relation to soil and crop needs. On this basis, FAO (1980) warned that it is not enough to apply the right kind and amount of fertilizer, manure or soil amendment, for efficient use, they must be applied at the right time and in the right way. This raises serious questions, which challenges the credibility of extension agents and their services among small-holder farmers in the zone over the years. Such questions as these arise: are small-holder farmers aware of the basic characteristics of the different fertilizers commonly used? do they adopt proper application methods? do they apply the fertilizers at the appropriate time? do the farmers relate the fertilizers to crops? and do they use the appropriate rate to attract a yield response. In an attempt to address the above questions, the study is aimed at identifying the impediments to efficient fertilizer application amongst small-holder farmers on marginal soils of Aba Agricultural Zone, Nigeria.

\section{MATERIALS AND METHODS}

The study was carried out in Aba agricultural zone of Abia state, Nigeria. The population of the study included all small-holder farmers in the 13 blocks of the zone. A double-stage random sampling was carried out to select five (5) blocks and 50 small-holder farmers from each block to realize 250 respondents for data collection. The responses to the respective items on basic characteristics of fertilizer; application methods; appropriate time of application; relating fertilizers to crops; and rate to attract a yield response were designed on a 5-point type summated rating scale of agreement (strongly agree, agree, undecided, disagree and strongly disagree). The values of the scale $(5,4,3,2,1)$ were summed up to obtain 15. The average of the sum gave 3.00. Decision was based on an overall mean realized from the mean on each item while the decision rule was 3.5 and above as being acceptable and below that as unacceptable.

\section{RESULTS AND DISCUSSION}

The results in Table 1 indicate an overall mean of 4.34 which show that farmers in the study are aware of the basic characteristics of the different fertilizers commonly used. However, the awareness of fertilizer characteristics does not necessarily imply efficient usage. This because farmers may be aware of fertilizer characteristics but faced with some other factors that may limit their access to the use of adequate fertilizers to attract a yield response. 
Table 1: Small-Holder Farmers Awareness of the Basic Characteristics of the Different Fertilizers Commonly Used.

\begin{tabular}{llc}
\hline S/NO & \multicolumn{1}{c}{ Items } & Mean Score \\
\hline $1 . \quad \begin{array}{l}\text { Arable crop growth and yield in this area depends among } \\
\text { other factors on major nutrient as nitrogen, potassium and } \\
\text { phosphorus. }\end{array}$ & 4.71 \\
2. & $\begin{array}{l}\text { all nitrogenous fertilizers are generally soluble, mobile } \\
\text { and easily washed off the soil to the detriment of your crops. }\end{array}$ & 4.27 \\
3. $\quad \begin{array}{l}\text { Early maturing crops may not utilize fertilizer phosphorus } \\
\text { and potassium because they don't dissolve easily in the soil }\end{array}$ & 3.64 \\
& $\begin{array}{l}\text { It is possible to identify a particular nutrient deficiency through } \\
\text { observable symptoms on crop performance without necessarily }\end{array}$ & 4.43 \\
& $\begin{array}{l}\text { a soil test. } \\
\text { Compound fertilizers (NPK) are preferred to single Fertilizers such }\end{array}$ & 4.67 \\
as urea, etc. Over all mean & 4.34 \\
\hline
\end{tabular}

From the above Table an over all mean value of 4.34 indicates that small-holder farmers are highly aware of the basic characteristics of the different fertilizers commonly used.

Further more, result in Table 2 (overall mean $=2.83$ ) showed that small-holder farmers do not adopt proper method of fertilizer application to their various crops. Inefficient method of fertilizer application as shown in the results has been responsible for failure by farmers to secure increases in crop yield (Collings, 1955; FAO, 1996; FUC, 1980).

Table 2: Proper Fertilizer Application Method as adopted by Small-Holder Farmer.

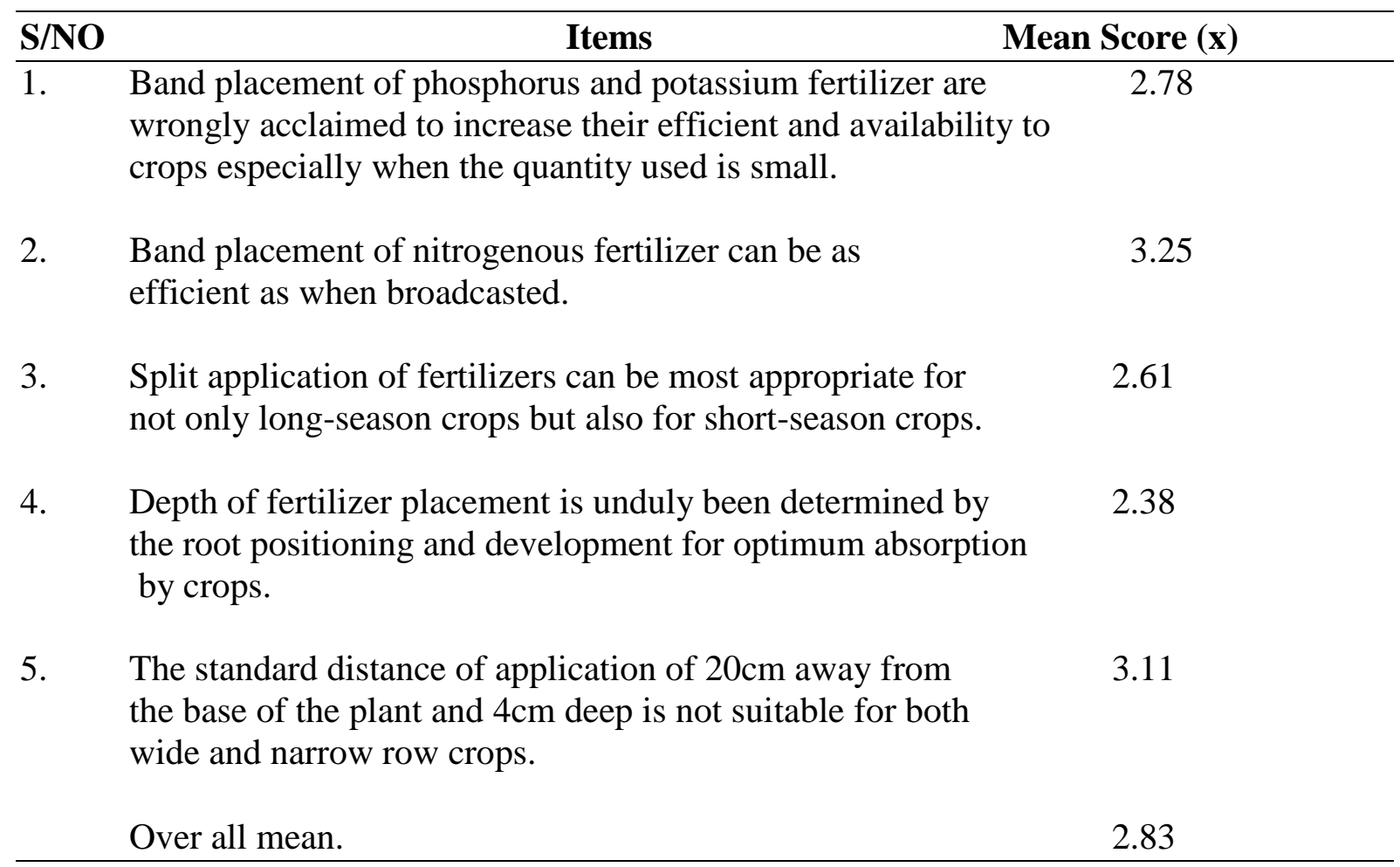


With 2.83 as overall mean from Table 2 shows that small-holder farmers do not adopt proper methods of fertilizer application.

As further indicated in Table 3 (overall mean $=3.20$ ), small-holder farmers do not apply fertilizers to their crops at the appropriate time. This therefore accounts for the dismal performance of various food crops in the study area. This finding corroborates Forth et al (1988). Application of fertilizers at the wrong time among small-holder may be due to institutional bottlenecks associated with fertilizers distribution in Nigeria.

Table 3: The Appropriate Timing of Fertilizer Application among Small-Holder Farmers.

\begin{tabular}{llc}
\hline S/NO & \multicolumn{1}{c}{ Items } & Mean Score $(\mathbf{x})$ \\
\hline 1. & $\begin{array}{l}\text { The satisfactory time to broadcast all nitrogenous } \\
\text { fertilizers on many loams, clayey-loams is at planting time }\end{array}$ & 3.00 \\
2. & $\begin{array}{l}\text { For effective utilization, all phosphorus and potassium } \\
\text { fertilizers are better applied at or immediately before planting. }\end{array}$ & 2.77 \\
3 & $\begin{array}{l}\text { Split application of all NPK fertilizers should be before seeding } \\
\text { time and/or during the seedling growing period. }\end{array}$ & 3.14 \\
& $\begin{array}{l}\text { Fertilizers applied late in the growing season do not attract } \\
\text { a yield response even if absorbed by crops. } \\
\text { Overall mean }\end{array}$ & $\mathbf{3 . 2 0}$ \\
\hline
\end{tabular}

The overall mean of 3.20 from Table 3 revealed that small-holder farmers do not apply fertilizers to crops at the appropriate time.

Table 4: The Use of Fertilizers in Relation to Crops as shown by Small-Holder Farmers

\begin{tabular}{llc}
\hline S/NO & \multicolumn{1}{c}{ Items } & Mean Score (x) \\
\hline 1. & Urea is good for vegetables & 4.68 \\
2. & NPK 10: 10:17; 15:15:15:15, 12:12:17-2 are useful for & 3.98 \\
& Cassava & \\
& & 3.60 \\
3. & Yam species yields optimally with NPK 15:15:15, & \\
& 12:12:17-2 & 4.00 \\
& & 3.74 \\
4. & Cereal crops attains yield increase with NPK 17:10:10 & 3.82 \\
5. & Horticultural crops do well on NPK 15:15:15, 12:12:17-2 \\
6. & $\begin{array}{l}\text { Cocoyam responds well with compound fertilizer } \\
\text { 15:15:15, 12:12:17-2 }\end{array}$ \\
7 & Legume crops depend heavily on phosphate fertilizers & 4.20 \\
& Overall Mean & $\mathbf{4 . 0 0}$ \\
\hline
\end{tabular}

Result in Table 4 showed an overall mean of 4.00 which implies that small-holder farmers relate fertilizers to crops properly. Result in Table 4 (mean $=4.00)$ shows that farmers relate the fertilizer to the corresponding crops in their farm. However, Table 5 revealed that smallholder farmers do not apply appropriate rate of fertilizers to attract a yield response (mean 
$=2.72$ ). This situation might be due to the scarcity and exorbitant cost of the fertilizers beyond the reach of small-holder farmers.

Table 5: Rate of Fertilizer Application among Small-Holder Farmers.

\begin{tabular}{llc}
\hline S/NO & \multicolumn{1}{c}{ Items } & Mean $(\mathbf{x})$ \\
\hline 1. & $\begin{array}{l}\text { A hectare of maize farm consumes up to six (6) bags of } \\
\text { NPK during the farming season. }\end{array}$ & 2.80 \\
& & 2.40 \\
2. $\quad \begin{array}{l}\text { The overall quantity of fertilizer for a hectare of cassava- } \\
\text { yam intercrop was more than 8 bags of NPK 15:15:15 }\end{array}$ & 2.95 \\
& $\begin{array}{l}\text { You procured more than 8 bags of urea for application in } \\
\text { your vegetable and garden egg farm. }\end{array}$ \\
& \\
& Overall Mean & $\mathbf{2 . 7 2}$ \\
\hline
\end{tabular}

As seen from Table 5, the overall mean of 2.72 revealed that small-holder farmers do not apply the appropriate rate of fertilizers to attract a yield response.

\section{CONCLUSION}

Crop yields has remained at minimum level despite the awareness of the potentials of chemical fertilizers to increase soil fertility and consequently crop growth and yield due to wrong application methods, wrong time of application and wrong rate of application among small-holder farmers. It is therefore recommended that extension agencies should step up their services to reach the small-holder farmers. All brands of fertilizers should be made available to farmers at subsidized rate at the right time through extension services centres.

\section{REFERENCES}

Collings, G.H.(1955). Commercial Fertilizers, Their Sources and Use. New York, McGraw Hill Book Company Inc. pp.75-94.

FAO (1960). Efficient Use of Fertilizers. Agricultural Studies No. 43 Rome FAO publications pp. 174-186.

FAO (1966). Statistics of Crop Responses to Fertilizers. FAO Publications. Pp 45-52

FAO (1983). Fertilizer and their Application to Crops in Nigeria. Fertilizer Use Series No. 1. Pp. 15-34.

Iwuafor, E.N.O. \& Kuma, V. (1995). :Alley Cropping of Maize and Leucaena leucocephala in the Northern Guinea Savanna of Nigeria”. In kang, B.T.; Osiname, A.O. \& laurcis A. (eds). Alley Farming Research and development Proceedings of an International Conferences on Alley Farming. Ibadan, Nigeria, Pp. 211-225.

McGraw Hill Encyclopedia of Food, Agriculture and Nutrition (1977). Pp. 233-244.

Kang B.T. Attah-Krah A.N. \& Reynolds, L. (1999). The Tropical Agriculturalist: Alley Farming. London, Macmillan Education Limited Pp. 14-43. 